\title{
Pemberdayaan Pelaku Usaha Kuliner Melalui Pembentukan Kelompok Usaha Bersama (KUBE) di Karanganyar
}

\author{
Empowering of Culinary MSMEs through \\ the Establishment of a Business Group in Karanganyar
}

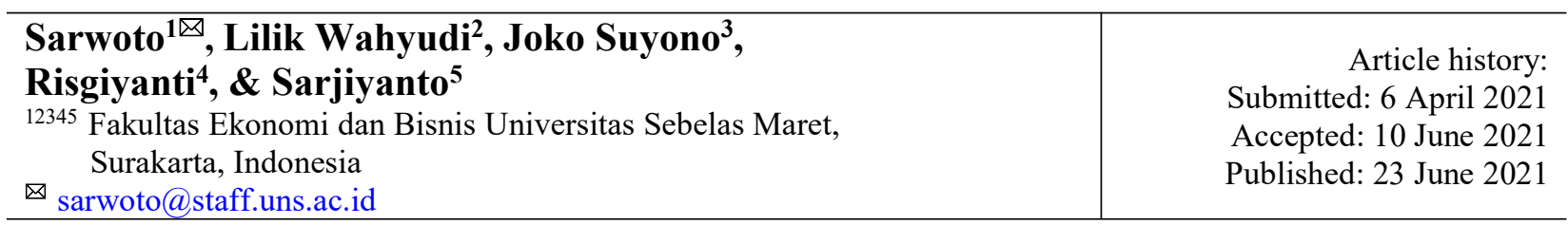

\begin{abstract}
The community partners in this empowerment program are culinary micro, small, and medium enterprises (MSMEs) in Cangakan, Karanganyar. The problems faced by them are related to institutional, managerial, and capital aspects, hence the program was aimed to empower and strengthen them through the establishment of KUBE (Business Group). The method used to solve problems is education to the community through training and mentoring to establish group institutions in KUBE of culinary, as well as empowering community members through institutional strengthening and entrepreneurship training. The result of this program is the establishment of a strong institution from the culinary MSMEs in Cangakan Karanganyar. Through the KUBE that is formed, it is hoped that it can be a solution in overcoming the problems faced.
\end{abstract}

Keywords: culinary MSMEs; empowerment; KUBE (Business Group); training \& mentoring

\begin{abstract}
Abstrak: Mitra masyarakat dalam program pemberdayaan ini adalah usaha mikro, kecil, dan menengah (UMKM) kuliner di Cangakan, Karanganyar. Permasalahan yang mereka hadapi terkait dengan aspek kelembagaan, manajerial, dan permodalan, maka program ini ditujukan untuk memberdayakan dan memperkuat mereka melalui pembentukan KUBE (Kelompok Usaha Bersama). Metode yang digunakan untuk mengatasi permasalahan tersebut adalah edukasi kepada masyarakat melalui pelatihan dan pendampingan yang bertujuan untuk membentuk kelembagaan kelompok di KUBE kuliner, serta pemberdayaan anggota komunitas melalui penguatan kelembagaan dan pelatihan kewirausahaan. Hasil dari program ini adalah terbentuknya kelembagaan yang kuat dari UMKM kuliner di Cangakan Karanganyar. Melalui KUBE yang dibentuk, diharapkan dapat menjadi solusi dalam mengatasi permasalahan yang dihadapi.

Kata kunci: KUBE (Kelompok Usaha Bersama); pelatihan \& pendampingan; pemberdayaan; UKM kuliner
\end{abstract}




\section{Pendahuluan}

Kelurahan Cangakan, Kecamatan Karanganyar, Kabupaten Karanganyar, Provinsi Jawa Tengah, merupakan salah satu daerah di Karanganyar yang banyak tumbuh kembang pelaku usaha kuliner. Lokasi Cangakan yang dekat dengan pusat kota dan alun-alun Kabupaten Karanganyar menjadikan daerah ini ramai dikunjungi warga untuk sekedar rekreasi ringan. Kondisi inilah yang menunjang tumbuh kembangnya usaha kuliner di sana: mulai dari Usaha Mikro Kecil dan Menengah sampai dengan kuliner besar dan ternama dalam bentuk cabang maupun franchise. Menurut Menteri Pariwisata Arief Yahya yang dimuat dalam harian Kabarbisnis.com (2019), Kabupaten Karanganyar memang menawarkan sensasi wisata kuliner yang tak berkesudahan. Pusat kuliner tersebar luas di kawasan sepanjang jalur utama. Mulai dari Palur, alun-alun dan plaza bisnis di Kelurahan Cangakan sampai dengan wisata kuliner di kawasan Taman Pancasila yang berjubel jumlahnya. Pelaku usaha kuliner yang dari UMKM didominasi oleh warga lokal Cangakan, Karanganyar, sedangkan pelaku usaha kuliner yang besar merupakan cabang dari usaha yang sudah mapan dari luar kota maupun franchise.

Perkembangan wisatawan sekarang adalah datang ke suatu daerah wisata untuk mencari atau berburu makanan khas daerah tersebut dan tidak segan-segan membayar mahal umuk menikmati suatu hidangan (Rismiyanto dan Danangdjojo, 2015). Peran kawasan sentra usaha kuliner seperti Pujasera (Pusat Jajanan Selera Rakyat) dan sejenisnya memiliki pengaruh yang besar pada perekonomian di suatu daerah, termasuk di Karanganyar, karena untuk membangun sebuah kawasan industri kecil ini tidak membutuhkan modal yang besar namun mampu menyerap tenaga kerja banyak (padat karya). Keberadaan industri kecil juga memiliki kontribusi yang besar pada perkembangan perekonomian suatu daerah, karena dengan jumlah unit usaha yang banyak menciptakan lapangan pekerjaan serta mampu menyerap tenaga kerja sehingga berpotensi untuk mengurangi pengangguran di suatu daerah (Sasmito dkk., 2021).

Namun, terdapat masalah utama yang dihadapi oleh pelaku usaha kuliner di Cangakan Karanganyar, yakni nilai tambah produknya yang relatif kecil. Hal ini disebabkan oleh modal yang kecil sehingga kesempatan berekspansi menjadi terbatas, sumber daya manusia yang relatif rendah sehingga tingkat kreatifitas dan inovasi produksi juga rendah, pemasaran yang dimiliki terbatas, sistem manajemen organisasi belum berjalan dengan baik. Dengan demikian, proses pemberdayaan kawasan wisata kuliner di kawasan kuliner Cangakan Karanganyar menjadi keharusan untuk dilakukan, khususnya oleh Pemerintah Kabupaten Karanganyar di era otonomi daerah ini, jika tidak ingin tertinggal dan tersingkir dari perkembangan ekonomi di era pasar bebas mendatang.

Permasalahan yang dihadapi pelaku usaha kuliner Karanganyar adalah tentang belum kuatnya posisi tawar mereka dalam struktur pasar dan perekonomian yang ada. Mengingat kelompok usaha kuliner Kanganyar mulai tumbuh dan berkembang namun belum adanya asosiasi atau ikatan antar kelompok sejenis yang bersifat permanen dan kuat, maka masalah kelembagaan perlu juga mendapatkan perhatian khusus agar keberlanjutan bisnis dapat dicapai. Kekuatan kelembagaan merupakan aspek yang penting dalam menjamin keberlanjutan bisnis di berbagai sektor (Yuniati dkk., 2018, Kusmanto dan Warjio, 2019, Khairunisa dkk., 2019). Ketika pelaku usaha mikro kecil dan menengah berjuang secara individual di dalam persaingan pasar yang sangat ketat tentu saja akan lebih sulit jika dibandingkan dengan ketika pelaku UMKM bersatu 
padu dalam sebuah asosiasi dalam menghadapi persaingan. Adanya kelembagaan atau asosiasi menjadikan UMKM berdaya saing yang lebih baik (Mustaqim dkk., 2018).

Pelaku usaha kuliner Karangnyar yang jumlahnya kurang lebih 250 unit ini, saat ini masih berjalan masing-masing tanpa ada koordinasi serta komunikasi di antara mereka, meskipun menjalanan usaha sejenis di satu kawasan yang sama. Oleh karena itu, untuk meningkatkan posisi tawar dan daya saing pelaku usaha kuliner Karanganyar dengan pelaku kuliner pendatang dari luar Karangnyar, pemodal, dan struktur pasar kuliner yang lebih besar, maka pembentukan dan pemberdayaan kelembagaan pelaku usaha kuliner di Karanganyar menjadi sebuah kebutuhan. Berkaitan dengan masalah ini, Program Pemberdayaan Masyarakat yang diselenggarakan oleh Universitas Sebelas Maret, Surakarta, ini akan memberikan solusi melalui pembentukan, pendampingan dan pemberdayaan sentra pelaku usaha kuliner Karangnyar menjadi sebuah Kelompok Usaha Bersama (KUBE) Pelaku Usaha Kuliner Karanganyar yang kuat dan berdaya saing, sehingga mampu mempertahankan keberlanjutan bisnisnya.

Permasalahan-permasalahan yang dihadapi oleh pelaku usaha kuliner Karanganyar, berdasarkan studi awal, akan diberikan solusi yang hendak ditawarkan melalui langkah berikut: (1) Tim Pengabdian melakukan pemetaaan awal terhadap segala permasalahan dan potensi yang ada pada Mitra dengan pendekatan Strengths (kekuatan), Weaknesses (kelemahan), Opportunities (peluang), dan Threats (ancaman) atau SWOT Analysis, (2) Melakukan Focus Group Discussion (FGD) dengan para pemangku kepentingan yang ada dan berkaitan dengan Mitra, (3) Melakukan pelatihan dan pendampingan kepada Mitra, dan terakhir (4) adalah evaluasi dan monitoring hasil pendampingan pada Mitra. Luaran yang dihasilkan dalam pengabdian ini adalah terbentuknya kelembagaan pelaku usaha kuliner Cangakan Karangnyar dalam sebuah Kelompok Usaha Bersama (KUBE) Kuliner beserta seperangkat kelengkapan organisasinya (pengurus, visi, misi lembaga dan program kerja).

\section{Metode Pengabdian}

Pelaksanaan pengabdian masyarakat ini menggunakan bentuk pendidikan kepada masyarakat. Bentuk pendidikan kepada masyarakat merupakan bentuk yang digunakan dalam pengabdian masyarakat yang berorientasi pada peningkatan sumberdaya manusia dalam mengelola dan menyelesaikan segala permasalahan yang dihadapi (Riduwan, 2016). Berdasarkan jenis kegiatan dalam bentuk pendidikan kepada masyarakat, Tim Pengabdi menggunakan pelatihan dan pendampingan UMKM untuk pelaksanaan knowledge transfer kepada UMKM dalam rangka peningkatan kualitas sumberdaya manusia pelaku UMKM kuliner Cangakan, Karanganyar.

Pelatihan yang dilaksanakan pada Program Pengabdian Masyarakat ini adalah Pelatihan Penguatan Kelembagaan dan Kewirausahaan bagi UMKM. Pelatihan dilaksanakan dengan pendekatan role playing agar peserta pelatihan mudah dalam memahami substansi pelatihan sehingga termotivasi untuk mengimplementasikan secara nyata. Selanjutnya, tindak lanjut dari pelatihan adalah pendampingan UMKM. Tim Pengabdi mendampingi UMKM dalam mengimplementasikan konsep-konsep yang diajarkan dalam pelatihan, salah satunya dengan dilakukan pendampingan dalam pembentukan Kelompok Usaha Bersama (KUBE). Berdasarkan sifatnya, pengabdian masyarakat ini termasuk ke dalam pengabdian masyarakat yang bersifat rintisan. Selama ini UMKM kuliner di Cangakan, Karanganyar belum mengenal adanya 
Pemberdayaan Pelaku Usaha Kuliner Melalui Pembentukan Kelompok Usaha Bersama...

Sarwoto, Lilik Wahyudi, Joko Suyono, Risgiyanti, \& Sarjiyanto

komunitas kelembagaan, sehingga Tim Pengabdi mengenalkan hal yang baru bagi UMKM kuliner di Cangakan, Karanganyar untuk mengatasi berbagai permasalahan yang dihadapi.

\section{Hasil dan Pembahasan}

\section{Pelatihan bagi UMKM}

Pelatihan yang diberikan kepada UMKM mitra adalah pelatihan penguatan kelembagaan dan kewirausahaan. Penguatan kelembagaan berkaitan dengan bagaimana merancang asosiasi pelaku usaha kuliner di Cangakan, Karanganyar, sedangkan kewirausahaan diberikan agar pelaku usaha kuliner di Cangakan, Karangayar dapat tumbuh berkembang menjadi wirausaha bukan sekedar pedagang kuliner.

Pelatihan Penguatan Kelembagaan dan Kewirausahaan dilaksanaan pada Rabu, 5 Agustus 2020 di rumah salah satu pelaku usaha kuliner di Cangakan, Karanganyar. Pelatihan disampaikan oleh Tim Pengabdi dengan dibantu oleh mahasiswa dan diikuti oleh UMKM kuliner di Cangakan, Karanganyar (Gambar 1).

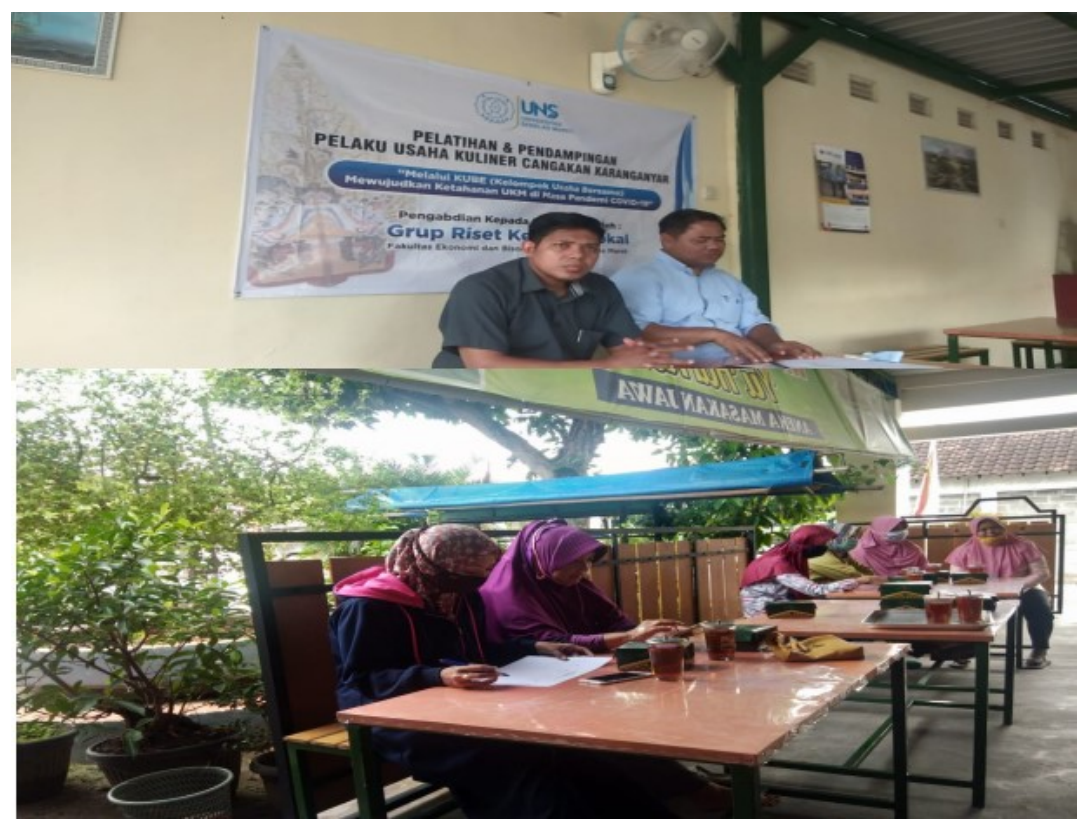

Gambar 1. Pelatihan Penguatan Kelembagaan \& Kewirausahaan

Materi pelatihan adalah penguatan kelembagaan dan strategi merumuskan tujuan usaha. Berkaitan dengan penguatan kelembagaan dikenalkan tentang organisasi, fungsi organisasi, dan peranan organisasi dalam menopang keberlangsungan usaha. Pada saat materi penguatan kelembagaan, peserta juga dikenalkan dengan "konsep uang setrika" yang menjadi pengantar pentingnya membina hubungan baik di dalam komunitas atau organisasi sehingga dapat menopang keberlanjutan usaha UMKM. Selanjutnya, juga dikenalkan tentang adanya Bank Kelompok yang dapat dilahirkan dari komunitas dengan prinsip dasar dari kelompok, oleh kelompok, dan untuk kelompok. 
Fokus materi pelatihan yang berkaitan dengan kewirausahaan adalah strategi merumuskan tujuan usaha. Pada materi ini dikenalkan model merumuskan tujuan usaha bagi para pelaku usaha. Selama ini, diyakini bahwa merumuskan tujuan sekedar menyampaikan angan-angan ke depan dan semua peserta menyebutkan tujuannya abstrak. Maka dalam pelatihan ini disampaikan mengenai Tujuan harus "SMART" yang berarti Specific, Measurable, Achievable, Relevant, dan Timely (Meyer, 2003). Perumusan tujuan merupakan hal yang penting bagi organisasi (Barney, 2002; Taiwo dkk., 2016; Bowen, 2018; Tanan \& Dhamayanti, 2020). Tujuan akan menentukan langkah-langkah yang akan diambil oleh organisasi termasuk UMKM. Maka dari itu, diperlukan rumusan tujuan organisasi yang spesific artinya rumusan tujuan harus spesifik dan jelas, tidak abstrak dalam mencantumkan apa yang akan dicapai perusahaan. Measurable berarti terukur, tujuan harus dapat diukur yang nantinya akan menjadi indikator kinerja bagi perusahaan. Achievable berarti tujuan yang dirumuskan adalah sesuatu yang dapat dicapai, artinya tujuan harus realistis. Meskipun terkadang rumusan tujuan sulit untuk dicapai, tetapi harus tetap realistis bagi perusahaan dengan memperhatikan berbagai karakteristik yang melekat pada perusahaan. Relevant berarti tujuan harus sesuai dengan karakteristik dan visi yang dibangun perusahaan. Timely berarti harus jelas kapan tujuan itu ditargetkan tercapai sehingga mudah dalam mengukur keberhasilan pencapaian tujuan. Dalam pelatihan juga dikenalkan strategi merumuskan tujuan dengan metode backward yang berarti metode mundur. Dalam pelatihan, peserta masih kesulitan merumuskan tujuan, dengan bahasa lisan menyampaikan tujuannya mengalir saja. Perumusan tujuan dengan metode backward digambarkan sebagaimana Gambar 2.

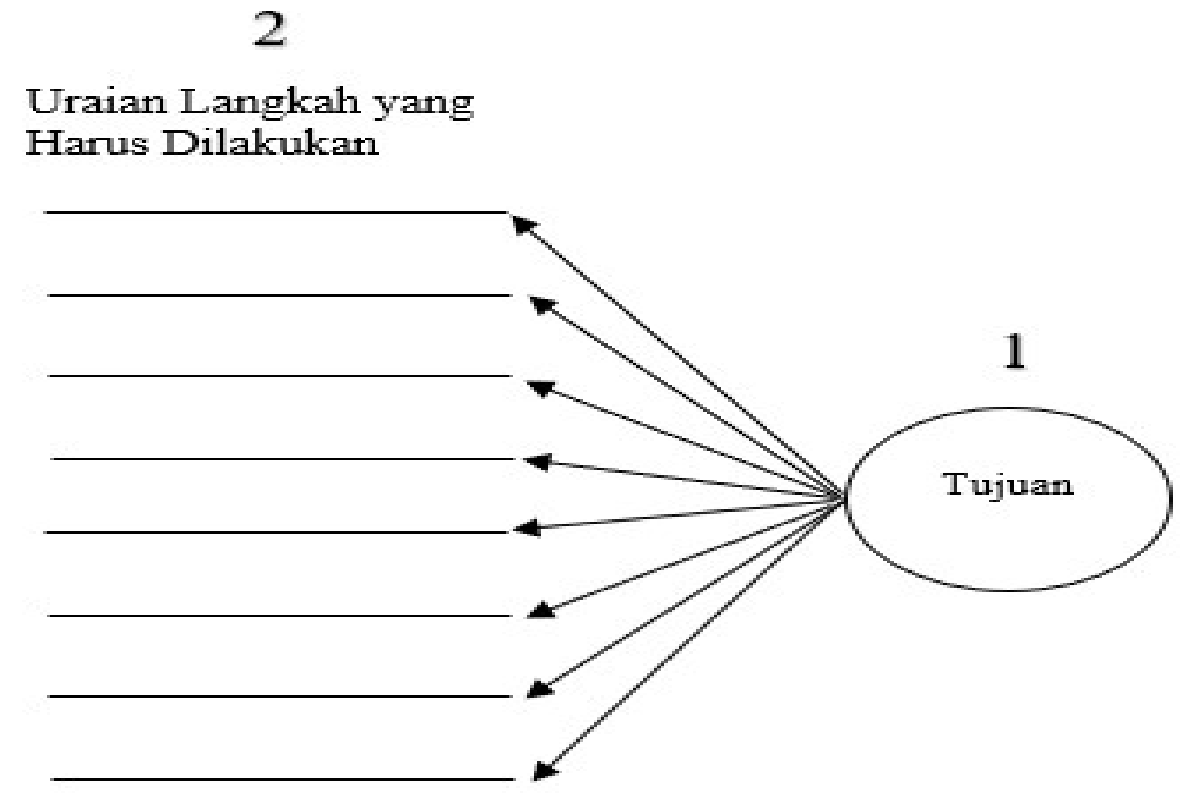

Gambar 2. Perumusan Tujuan dengan Metode Backward

Dalam merumuskan tujuan dengan metode backward, dilakukan dengan fokus merumuskan tujuan terlebih dahulu kemudian diikuti dengan mengurai langkah-langkah yang harus dilakukan untuk mencapai tujuan yang telah dirumuskan. Pendekatan ini merupakan hal yang baru bagi peserta pelatihan dan dilanjutkan dengan simulasi. Simulasi diberikan secara individual untuk mengukur pemahaman peserta atas materi yang disampaikan. Pada akhir sesi pelatihan, selain 
dilakukan evaluasi pemahaman materi pelatihan kepada peserta, juga dilakukan evaluasi kepuasan dari pelaksanaan pelatihan dengan membagikan angket kepada peserta.

Berdasarkan hasil simulasi yang dilakukan, menunjukkan bahwa peserta pelatihan memahami materi pelatihan dengan sangat baik dan dapat mengimplementasikan dengan kondisi nyata yang dialami. Selain itu, dari data angket yang dibagikan kepada peserta, evaluasi pelaksanaan kegiatan pelatihan menunjukkan tingkat kepuasan yang sangat tinggi dari peserta pelatihan atas pelaksanaan pelatihan yang dilakukan. Berdasarkan masukan dan saran dari angket tersebut, semua peserta berharap diselenggarakan program pelatihan dengan materi yang beragam sesuai dengan permasalahan yang dihadapi komunitas usaha.

\section{Pendampingan bagi UMKM}

Pendampingan bagi UMKM merupakan tindak lanjut dari pelatihan yang dilaksanakan, baik dari sisi kelembagaan maupun kewirausahaan. Dari sisi penguatan kelembagaan, dilakukan pendampingan dalam pembentukan kelompok usaha bersama pelaku usaha kuliner di Cangakan, Karanganyar. Sedangkan berkaitan dengan kewirausahaan, dilakukan pendampingan bagi UMKM dalam merumuskan tujuan. Pendampingan ini dilaksanakan selama 1 (satu) bulan terhitung sejak pelaksanaan Pelatihan Penguatan Kelembagaan dan Kewirausahaan (Gambar 3).

Setelah mendapatkan materi penguatan kelembagaan, peserta pelatihan yang juga pelaku usaha kuliner di Cangakan, Karanganyar menjadi termotivasi untuk membentuk kelompok usaha bersama. Pembentukan kelompok usaha bersama didampingi oleh Tim Pengabdian. Sebagai permulaan, peserta pelatihan dibagi ke dalam beberapa kelompok agar memudahkan koordinasi antara anggota dan efisiensi kelompok. Dalam pendampingan pembentukan kelompok usaha bersama juga dijelaskan mengenai kiat-kiat dalam membentuk dan memelihara kelompok agar tetap terjaga kebersamaannya dan memberikan manfaat ke semua anggota kelompok.

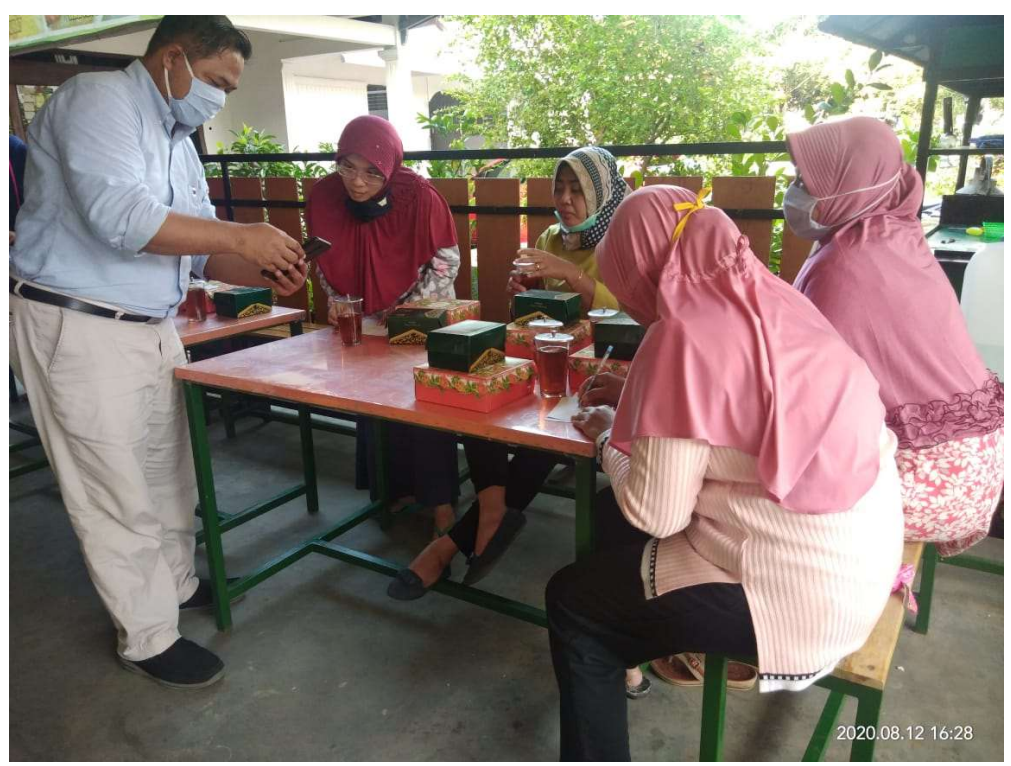

Gambar 3. Pendampingan Pembentukan Kelompok Usaha Bersama 
Selain itu juga diberikan pendampingan mengenai penyusunan program-program dalam rangka menumbuhkembangkan kelompok usaha bersama sehingga keberadaannya tidak menjadi beban masing-masing anggota tetapi memberikan manfaat bagi anggota kelompok. Pada saat yang bersamaan, terdapat informasi bantuan bagi UMKM pada masa pandemi COVID-19 dari Pemerintah Daerah Kabupaten Karanganyar, Tim Pengabdian juga mendampingi dalam memanfaatkan teknologi informasi untuk memanfaatkan program tersebut. Pembentukan Kelompok Usaha Bersama tentu saja perlu ditindaklanjuti pada proses pengurusan legalitas kelompok untuk mendapatkan pengakuan dari dinas terkait. Pengurusan legalitas kelompok juga didampingi oleh Tim Pengabdian.

Berkaitan dengan materi kewirausahaan, pendampingan dilakukan bagi UMKM dalam perumusan tujuan dan langkah-langkah untuk mencapai tujuan. Pendampingan dilakukan secara intensif dan individual kepada masing-masing peserta pengabdian. Masing-masing diberikan lembar kerja seperti yang disajikan pada Gambar 2, yaitu Perumusan Tujuan dengan Metode Backward untuk diisi dan dievaluasi oleh Tim Pengabdi dan diberikan penilaian mengenai aspek kecukupan pemenuhan indikator-indikator dalam perumusan tujuan. Monitoring dan evaluasi dilaksanakan oleh Tim Pengabdian pada awal, tengah, dan akhir dari pendampingan UMKM. Hasil monitoring dan evaluasi yang dilakukan menunjukkan bahwa pelaku usaha kuliner di Cangakan, Karanganyar, telah mengimplementasikan program yang ditawarkan dari pengabdian masyarakat ini dengan baik. Di antara bukti konkretnya adalah telah dibentuknya Kelompok Usaha Bersama Kuliner 45 untuk mewadahi pelaku usaha kuliner di Cangakan, Karanganyar.

\section{Kesimpulan}

Sebelum dilakukan kegiatan pengabdian masyarakat ini, pelaku usaha kuliner di Cangakan, Karanganyar, masih bersifat individual. Semua pelaku usaha yang menjadi mitra dalam pengabdian masyarakat ini belum memiliki ijin usaha dan belum mengenal tentang kelembagaan. Melalui program pengabdian masyarakat dengan bentuk pendidikan kepada masyarakat, pelaku usaha dikenalkan tentang prinsip dasar kelembagaan, arti pentingnya kelembagaan bagi sebuah usaha khususnya usaha mikro, kecil, dan menengah. Selanjutnya diberikan pelatihan dan pendampingan dengan metode role playing tentang bagaimana membentuk kelompok serta program-program yang relevan untuk menunjang keberlanjutan usaha khususnya bagi pelaku usaha yang kurang mampu dalam hal permodalan usaha. Di akhir program pengabdian, sudah mulai terbentuk Kelompok Usaha Bersama (KUBE) Kuliner 45 Cangakan, Karanganyar dalam rangka mewadahi seluruh pelaku usaha kuliner di Cangakan, Karanganyar dengan tujuan melindungi para pelaku usaha kuliner agar usahanya berkelanjutan.

\section{Ucapan Terima Kasih}

Terima kasih kepada Universitas Sebelas Maret yang telah menyetujui Program Hibah Pengabdian kepada Masyarakat dengan No. Kontrak 453/UN.27.21/PN/2020. 
Pemberdayaan Pelaku Usaha Kuliner Melalui Pembentukan Kelompok Usaha Bersama...

Sarwoto, Lilik Wahyudi, Joko Suyono, Risgiyanti, \& Sarjiyanto

\section{Referensi}

Barney, J. (2002). Gaining and Sustaining Competitive Advantage. New Jersey : Pearson Education, Inc.

Bowen, S. (2018). Mission and Vision. The International Encyclopedia of Strategic Communication. John Wiley \& Sons, Inc.

Kabarbisnis.com. (2019). 10 Kuliner Karanganyar yang wajib disambangi saat libur Lebaran. https://www.kabarbisnis.com/read/2891825.

Khairunnisa, K., Saleh, A., \& Anwas, O. M. (2019). Penguatan Kelembagaan Petani Padi dalam Pengambilan Keputusan Adopsi Teknologi IPB Prima. Jurnal Penyuluhan, 15(1). https://doi.org/10.25015/penyuluhan.v15i1.23460

Kusmanto, H., \& Warjio, W. (2019). Pentingnya Legalitas Usaha bagi Usaha Mikro Kecil dan Menengah. JUPIIS: JURNAL PENDIDIKAN ILMU-ILMU SOSIAL, 11(2), 324-327. https://doi.org/10.24114/jupiis.v11i2.13583

Meyer, PJ. (2003). Attitude Is Everything: If You Want to Succeed Above and Beyond. New York: Paul J. Meyer Resources

Mustaqim, F., Kusnandar, K., \& Agustono, A. (2018). Analisis Kelembagaan dan Strategi Peningkatan Daya Saing UMKM Emping Melinjo di Kabupaten Magetan. Jurnal Sosial $\begin{array}{llllll}\text { Ekonomi Pertanian dan } 14 & \text { (2): } & \text { 124-134. }\end{array}$ https://doi.org/10.20961/sepa.v14i2.25002

Riduwan, A. (2016). Pelaksanaan Kegiatan Pengabdian Kepada Masyarakat Oleh Perguruan Tinggi. Jurnal Ekonomi dan Keuangan, 3(2): 95-107. doi:10.24034/j25485024.y1999.v3.i2.1886

Rismiyanto, E., \& Danangdjojo, T. (2015). Dampak Wisata Kuliner Oleh-oleh Khas Yogyakarta terhadap Perekonomian Masyarakat. Jurnal Maksipreneur: Manajemen, Koperasi, dan Entrepreneurship, 5(1), 46-64. http://dx.doi.org/10.30588/jmp.v5i1.144

Sasmito, D., Putra, W., \& Sofyan, L. (2021). Nganjuk.Hitz: Sistem Informasi Pariwisata Berbasis 360-degree Tourism Web Guna Mengembangkan Destinasi Wisata di Kabupaten Nganjuk. Amalee: Indonesian Journal of Community Research and Engagement, 2(2), 75-87. https://doi.org/10.37680/amalee.v2i2.676

Taiwo, A., Lawal, F., Agwu, M. (2016). Vision and Mission in Organization: Myth or Heuristic Device? The International Journal Of Business \& Management, 4 (3): 127-134.

Tanan, C., \& Dhamayanti, D. (2020). Pendampingan UMKM dalam Pengelolaan Keuangan Usaha Guna Peningkatan Ekonomi Masyarakat di Distrik Abepura Jayapura. Amalee: Indonesian Journal of Community Research and Engagement, 1(2), 173-185. https://doi.org/10.37680/amalee.v1i2.408

Yuniati, S., Susilo, D., \& Albayumi, F. (2018). Penguatan Kelembagaan dalam Upaya Meningkatkan Kesejahteraan Petani Tebu. UNEJ E-Proceeding, , 498-505. Retrieved from https://jurnal.unej.ac.id/index.php/prosiding/article/view/6707 